\title{
MODERN COMPUTER SCIENCE AND LINGUISTICS
}

\begin{abstract}
Аннотация. В статье рассматриваются вопросы, связанные с вычислительной техникой и языковыми средствами. Вычислительная техника и информатика занимают сегодня в нашей жизни особое место. Антропоморфные метафоры, используемые в текстах по вычислительной технике, необходимь для передачи некоторого объема содержательной информаиии с минимальными языковыми затратами, коммуникативным и прагматическим эффектом. Диапазон лингвистических исследований довольно иирок: от лексикологии до грамматики, от разговорного языка до технического.

Ключевые слова: вычислительная техника, лингвистика, лингвистические исследования, метафора.

Abstract. The article deals with the problems of computer science and metaphor. Computer science and informatics are of great importance in our life. Anthropomorphous metaphors using in texts on computer science are necessary for transferring information rich in content with minimum language, communication and pragmatic effects. The range of linguistic researches is rather wide, from lecsicology to grammar and typology, from spoken speech to technical style.
\end{abstract}

Keywords: computer science, linguistics, linguistic researches, metaphor.

Вопрос об антропоцентризме в языке особенно активно начал обсуждаться в последнее десятилетие XX века (Кубрякова, Фрумкина, Апресян, Малинович, Малинович, Хомякова). По словам Н.Д. Арутюновой: «Язык насквозь антропоцентричен. Присутствие человека дает о себе знать на всем пространстве языка, но более всего оно сказывается в лексике и синтаксисе - семантике слов, структуре предложения и организации дискурса» [1]. Однако приоритеты лингвистики XX столетия были совершенно иными.

В качестве «точки отсчета» возьмем определение языка, сформулированное $\Phi$. де Соссюром. Ф. де Соссюр рассматривал язык как норму для всех прочих проявлений речевой деятельности, которую якобы нельзя изучать с разных позиций, поскольку язык в этом случае предстал бы перед исследователем как груда разрозненных явлений. Ф. де Соссюр предлагает отграничить лингвистику от таких наук как психология, антропология, нормативная грамматика, филология и т.д. $[13$, c. 47-48]. По мнению ученого, язык - это целостность сама по себе [13, с. 48].
Несколько иначе формулирует методологическую установку на науку о языке Г. Пауль. Непосредственной задачей языкознания, по Г. Паулю, является изучение тех отношений, в которые вступает совокупность представлений с определенными звуковыми комплексами. Для Г. Пауля важно было отмежеваться от психологизма и обосновать историю языка, которая должна стать единственной наукой о языке [12, с. 201].

Определить язык как «вещь в себе» характерно и для представителя глоссематики Л. Ельмслева. По его мнению, язык надо осознавать как самодовлеющую целостность, а не как конгломерат нелингвистических явлений.

Л. Блумфилд, признавая роль психологического фактора в языке, все же отказывается учитывать этот фактор: «Нам непонятен механизм, - пишет он, заставляющий людей в определенных ситуациях говорить определенные вещи, или механизм, заставляющий их надлежащим образом реагировать, когда те или иные звуки речи достигают их слуха». И несколько дальше эти механизмы изуча- 
ются в физиологии и особенно психологии $[4$, c. 46$]$.

Принимая в качестве исходной посылки биологической фактор - «врожденность», Н. Хомский считает, что исходной базой достоверного знания является не опыт, а интуиции, т.е. «врожденные идеи» $[15$, с. 10$]$.

Несмотря на то, что все эти ученые исключают из языка психофизиологические и психолингвистические факторы, однако, их идеи послужили основой, на которой развивались новые лингвистические направления относительно языка и роли психических процессов в нем.

Если говорить о современной лингвистике, то ее можно отнести к науке о человеке, точно так же, как это можно сказать о философии, психологии, антропологии. Однако, перечисленные выше «науки о человеке» имеют иное содержание. Лингвистика, как известно, занимается изучением естественного человеческого языка вообще, кроме того, лингвистика является частью семиотики, поскольку язык является знаковой системой.

Язык как форма существования знания в виде системы знаков является единственным инструментом, с помощью которого происходит коммуникация, трансляция и трансмутация [8, с. 10-11]. Еще Гумбольдт понимал язык как «мир, лежащий между миром внешних явлений и внутренним миром человека» [6]. По мнению Ю.С. Степанова, проблема антропоцентризма была поднята в работе Э. Бенвениста «Общая лингвистика», в которой ученый обращает внимание на такие глаголы антропоцентрической семантики, как «клясться», «обещать», «обязываться». У отмеченных глаголов означающее и означаемое совпадают по времени, т.е. их референциальная соотнесенность существует только в момент их произнесения, сюда же, Э. Бенвенист относит и личное местоимение «я» [3]. Все это позволило Э. Бенвенисту сделать вывод о «присутствии человека в языке». «Человек в языке» и выявление человеческого фактора в языке в середине XX века все еще не являлись фактором пристального внимания лингвистов.

Однако в настоящее время антропологический подход к языку достиг своего апогея. Человек, пропуская через свое сознание картину отраженного образа окружающего мира, воспроизводит ее с помощью языка. По меткому замечанию М.М. Бахтина, «человек в его человеческой специфике всегда выражает себя (говорит), то есть создает текст (хотя бы и потенциальный)» [2, с. 301].

Современная вычислительная техника и информатика занимают сегодня в нашей жизни особое место. Это связано с развитием научно-технических знаний и научнотехнического прогресса, которые требуют автоматизированной обработки и передачи информации в различных областях человеческой деятельности.

Благодаря вычислительной технике многие задачи и их решения стали намного проще. Что касается области коммуникации, то общение посредством компьютера позволило сократить огромные расстояния, сделав невозможное: за считанные минуты, передав необходимую информацию, можно рассчитывать на быстрый ответ.

Сегодня человечество не мыслит себя без современной вычислительной техники. В своем развитии техника, как и человеческая цивилизация, прошла несколько этапов. Она стала необходима человеку уже на ранней стадии его эволюционного развития. Первые орудия человек проецировал согласно формам своих органов бессознательно, лишь воспроизводя самого себя. С эволюционным развитием человека идет дальнейшее преобразование орудий. Человек постепенно переходит от имитации внешних форм к образцам своего организма, как единого целого. По словам Э. Каппа «связь между механической функцией и данным органическим образованием строго предопределена. Так узнают себя друг в друге лупа и глаз, дрожащая струна и ухо, насос и сердце, труба и горло. Будучи открыта, эта связь используется самым разнообразным способом в сознательном перенесении за пределы первоначальных отношений» [7]. Естественное переплетение техники с человеком отражается в его сознании, а с помощью языка человек упорядочивает отношения к предметам и явлениям внешнего мира. Стремительное развитие науки и техники, открытия и изобретения сложнейших аппаратов и механизмов требовали их популяризации не только в научной сфере. С развитием науки и техники 
развивается и стиль изложения, требуются новые языковые средства выражения. Доступность сложных описаний, их наглядность предъявляют к языку особые требования. Язык технических текстов должен сочетать в себе элементы, как научного повествования, так и характерные черты других стилей языка. Язык как постоянный процесс переструктурирования семантического поля обеспечивает нас метафорами необходимыми для освоения потока новой информации и в какойто степени выполняет функцию средства, обеспечивающего адаптацию человека к изменяющимся условиям. Метафора по отношению к языку является его динамическим принципом. Каждое новое открытие расширяет ресурсы языка, добавляя к его запасам новые метафоры, так что язык по преимуществу развивается более экономичным и плодотворным способом - путем метафоризации. Следует отметить, что благодаря метафоре существенно расширяются возможности информативной функции языка, создаются структуры, обладающие возможностью более точного отражения явлений действительности [5, с. 19].

Мы полагаем, что изучение процессов метафоризации и метафоричности технических текстов является наиболее репрезентативной сферой, это связано с развитием научно-технического прогресса и научнотехнических знаний. Кроме того, необходимо отметить, что весь научный потенциал, в целом, на этапе реализации научного знания предполагает выход в систему обучения, культуры и прагматической деятельности, поэтому проблемы понимания при изложении сложнейших технических процессов имеют огромное значение, именно здесь решающим является умение использовать определенные средства языка, его универсальность и емкость.

Местом, позволяющим перейти с научного языка с его сложнейшими абстракциями на естественный язык и с естественного языка на научный, служит метафора, которая, как известно, основана на аналогии. Ассоциативные связи, возникающие при метафорическом переносе, имеют место благодаря фундаментальным человеческим концептам, которые являются врожденными, но их реализация зависит от языка как орудия культуры. Врожденность фундаментальных человеческих концептов можно объяснить тем, что наши категории и формы восприятия зафиксированы до нашего индивидуального опыта и адаптированы к внешнему миру [11, с. 19].

В процессе метафорического творчества происходит концептуализация внеязыковой действительности в направлении от познания конкретного к познанию абстрактному. Известный советский психолог А.А. Леонтьев считает, что возникновение базовых концептуальных структур исходит из структурной природы опыта и врожденных способностей, благодаря которым происходит преломление конкретики на уровне абстракции [10, с. 21].

Следует отметить, что человек, его тело, его организм, его физические, социальные и психические свойства и качества стали источником антропоморфных метафор в технических текстах по вычислительной технике.

Определяющая роль человеческого фактора в языке особенно широко проявляется в семантике метафоры. Антропоморфные метафоры широко представлены в научной картине мира, и, в частности, в технике. Антропоморфность и антропоцентризм, появляющиеся в метафоре, свидетельствуют о том, что человек осознал себя центром Вселенной, выделил себя из окружающего мира.

Антропоморфные метафоры, используемые в текстах по вычислительной технике, необходимы для передачи некоторого объема содержательной информации с минимальными языковыми затратами, коммуникативным и прагматическим эффектом.

Рассмотрим следующие примеры, в которых активным деятелем является компьютер. Внешне неодушевленный предмет компьютер не похож на человека. Однако подобно одушевленному существу неодушевленный предмет наделяется способностью совершать подобно человеку активные действия: «Most of the benefits that computers bring us are invisible. Computers help people to design everything. Computer-generated graphics have opened up new world of artistic possibilities. Computers help farmers maximize their yields. Even though some of these computer applications may worry us...» [16, c. 8-9]. 
В приведенных выше примерах компьютер выполняет функции, свойственные человеку, а именно: приносить (bring), помогать проектировать (help to design), открывать (open), беспокоить (worry). Мы воспринимаем компьютер как живое существо (человек), «приписываем» ему многие свойства и качества человека, и все это отражается в языке. По нашему мнению, это объясняется тем, что происходит переструктурирование понятийных сфер на основе фундаментальных человеческих концептов. Метафорическое представление машины идет через понятие «человек», то есть физический объект конкретизируется с помощью человеческих качеств, иначе, говоря, персонифицируется.

\section{СПИСОК ЛИТЕРАТУРЫ}

1. Арутюнова Н.Д. Язык и мир человека / Н.Д.Арутюнова. - 2-е изд., исп. и доп. - М.: Языки русской культуры, 1999.

2. Бахтин М.M. Проблема текста // Вопросы литературы, 1976. - С.122-152.

3. Бенвенист Э. Общая лингвистика и вопросы французского языка / Э. Бенвенист. Пер. с франц. - М.: Прогресс. 1974.

4. Блумфилд Л. Язык. Пер. с англ. / Л. Блумфилд. - М.: Прогресс, 1968.

5. Глазунова О.И. Метафора в художественном тексте I // Вестник СПб университета, 2001, серия 2, выпуск 2. - С. 41-52.

6. Гумбольдт В. фон. Избранные труды по языкознанию. Пер. с нем. / В. фон Гумбольдт. - М.: ОАО ИТ. Прогресс, 2000.

7. Капп Э. Философия машины // Роль орудия в развитии человека. Под ред. И.С. Плотникова. Л., 1925.

8. Колесов В.В. Философия русского слова. - С.Петербург, 2002.

9. Кубрякова Е.С. Эволюция лингвистических идей во второй половине 20 века (опыт парадигмального анализа) // Язык и наука конца 20 века. - М., 1995.

10.Леонтьев А.А. Психолингвистические единицы и порождение речевого высказывания / А.А. Леонтьев. - М.: Наука, 1969.

11.Лоренц К. Кантовская теория а priori в свете современной биологии / Эволюция. Познание. Язык. - М.: Языки русской культуры, 2000.

12.Пауль Г. Принципы истории языка. Пер. с нем. / Г. Пауль. - М.: Изд-во иностр. лит-ры, 1960.

13.Соссюр Ф. Курс общей лингвистики. - М., 1999

14.Степанов Ю.С. Методы и принципы современной лингвистики. - М., 2001.

15.Хомский Н. Аспекты теории синтаксиса. Пер. с англ. / Н. Хомский. - М.: Издво МГУ, 1972.

16.The Mind Tool. Computers and Their Impact on Society. Fourth Edition / Ed. Neill Graham, 1986. 